\title{
Philosophical Thinking of Student Participation
}

\author{
Kong Lisu \\ The Research Institute of Higher Education in Yibin University, Yibin, Sichuan, China
}

\begin{abstract}
In recent years, student participation has become a major trend in the development of higher education. Countries are increasing emphasis on the role of student participation. It is necessary to think and the explore the philosophical significance of student participation, providing a strong philosophical basis for students to participate in university management.
\end{abstract}

KEYWORD: Student; Participation; Philosophical thinking

\section{INTRODUCTION}

Student participation in university management can be traced back to guilds of medieval Europe. Guilds are the organization for the same industry protecting the interests of members[1], which is the first kind of student participation in school management practices. It was the foundation of student participation in school management. With the evolution of the development of student guilds, the groups size of the student organization increases gradually. University of Bologna in early 12th century is the most representative of the student participation university. It is the originator of "Student University" which students manage school and teachers obey school chapter. And it has a profound impact for later student participation in school management".

In recent years, student participation in university management has become a major trend in the development of higher education. Countries are increasing emphasis on the role of student participation. It has become an important part in university management, which effectively alleviate the contradiction between the school and students, and promote the healthy development of university education self-restraint and self-renewal capacity.

Here we will discuss the following aspects philosophical significance of student participation in the university management.

\section{ACADEMIC AUTONOMY}

Student participation is in the bottom layer of the Grade ladder of academic autonomy, one of which is also the most important grade. In his book "Philosophy of Higher Education", higher renowned expert John Brubaker devoted specifically with a section to illustrate the necessity and importance of student participation. The book describes the student participation in school management committee, to ensure school's organic operation, coordination and development. He said, "wise power-sharing does not mean weakening the powers, but can produce more achievement." Student participation in management is an important step in the democratization and efficiency of university management. Due to the participation of students, they feedback, find contradictions and problems, to help managers and teachers looking for weak links of management, then clear directions for improvement, and get advice on how to improve the reference. Their views are fully reflected and the intentions of university administrators also get their understanding, which makes it easy to reach down harmonized and contribute to implement efficiency of university management.

According to Jefferson's theory, all decisions which have an important relationship with the students should solicit student opinions (Wolfe, 1969). As consumers of higher education, students require a certain degree of right in determining the curriculum and teachers' appointment, promotion, dismissal.[2] These requirements is reasonable. Students are not only the important subject of education management, but also the focus point of school education management activities. As managed objects, Students give managers recognition, cooperation and support to management activities, which will form a benign operation force together with teachers and administrators. Also as 
the majority members in special educational organization groups, college student are young and energetic, active thinking and innovative, academically can provide input of importance.

Of course, some scholars believe that the University is not an egalitarian society, but hierarchical society (Hoffman, 1974).[2] And neither college nor university is a political organization (Hooker, 1969; Cohen, 1975). Its duty is not to the administration, but discovery, publication and teaches profound knowledge. Its management is not subject to the principle of majority or minority according to the number, but based on knowledge.[2] Compared with teachers, students, after all, belongs to those who seek knowledge. It is impossible for them to enjoy the same rights with teachers in the field of profound knowledge. Otherwise, it just might make academic quality compromised.

In addition, history has proven that when the process of rational setbacks, there is a risk of non-rational process instead. If the school management process never solicit the views of students, or listened to the views of students but did not do so, it will cause student discontent. And the accumulation of students' dissatisfaction will become breakage, and then turn into a riot. Such consequences will be disastrous. Some students have tried to resort to "student power" (Jones pass, 1969), to resolve their differences between teachers and management agencies.[2]

This means that student participation has its necessity and feasibility. It is important to grasp the degree of the problem. Only in ensuring academic quality without any damage to the premise can that students involved in really meaningful.

\section{STUDENT VOICE}

Word is the main way of expressing itself primarily thoughts, feelings, attitudes, and it always represented a kind of power. Postmodern philosopher Michel Foucault believe that "discourse is a power relationship, it means who say, who no voice". "Although it is a hidden system without the perpetrator's control on the surface, it is a real power in society." In fact, the power of language is not from itself. Since the symbol system produced it was only communication and thinking tools between people. Discourse of power is the refraction and reflection of speaker's social power and status in symbol system. Student's right to speak is that students of particular group in educational activities, especially in the classroom have the right to express their thoughts, feelings and opinions. It contains not only the initiative right of the students to express their true thoughts and feelings during class by communicating with teachers and students, but also includes the right of students performing their ideas in the form of a written achievements.

In addition, the discourse is the particular symbol system that is intuitive and vivid expression of individual life. According to Western scholars David Griffin, Hoy Rorty ecological worldview, in the society constituted by different discourses, there is no supreme authority and the final rules; each participant can from their own speech or narrative; everyone has the right to express their own opinions. Therefore, in the current era of education with purpose of achieving people-oriented management and subjective education, the students' right to speak establishes not only through the status of students in the classroom, but also through consciousness prominent by student participation in university management. It is the right that student as a "person" should have.

First of all, in teaching activities in the class, teachers and students are to participate in teaching activities with their whole life. Class activities are not transfer process of abstract knowledge, but the main activities of experience exchange between teachers and students. Students in the classroom exist as complete individual life, and their discourse expressing is the inherent need of their full life. Therefore, return to students' life discourse, to the integrity of students' life discourse, so as to "let the classroom full of vitality". Secondly, as the vast majority of college basic member, students think they have the right to make recommendations and opinions on school management activities as the same as teachers. So the students participate in university management itself is to achieve the students' right to speak, and it is the most effective and direct way to establish the student status. Thirdly, because of the participation of students, they feedback, find contradictions and problems, to help managers and teachers looking for weak links, and then clear directions for improvement, get advice on how to improve the reference. On the one hand, their views are fully reflected, highlighting the student's right to speak; on the other hand, the intention of university administrators also gets the students' understanding. It is beneficial to establish a harmonious campus and implement democratization and efficiency management.

\section{STUDENTS SUBJECTIVITY}

The student subjectivity is mainly refers to autonomy, initiative and creativity of college students demonstrated in educational activities. It is normal activities of teaching and administrative, and necessary impetus to constantly improve the quality of teaching.

First of all, Marxism believes that as a human, activity is the fundamental way existence and 
development. The main reason why a human to be a human is that human has his own object-oriented, specific activities. Only in the activity of subject objectification and subjective object, can people confirm themselves, to express themselves, and transform themselves in order to achieve their own development. Marx established on the basis of human reality objectivity, also highlighted the human conscious initiative. He thinks that human activities are not satisfied with simple copy the objective environment and historical conditions of the outside world, but always do everything possible to "apply the inner scale to the object".

Fundamentally speaking, the human subjectivity is generated by the activities and development activities given in activities. Only in social practice and exchanges, can human capacity and personality get development; also only through widespread exchanges with others or groups, can make themselves into historical existence in the world community, can obtain social personalized individual provisions of the historic nature of the world, then make their own subjectivity to develop. That is to say, the students' existence and development in the field of education is through participation. Only by participating in class activities and school management activities, can students' consciousness, capacity and the main character be raised, the dominant position be confirmed. Only in the course of participating in activities, can the subjectivity of students be developed.

Secondly, according to Habermas' communication theory, "subject has those skills and qualifications by obtaining verbal and functional operations; that due to these capabilities and qualifications, the subject gets the functions of mutual understanding involved in the process, in which determine his own identity and characteristics"[6] Play the subjectivity reasonable is inter-subjectivity. Habermas emphasizes that subjectivity in the form of social and cultural life can not live without exchanges with each other, and also can not have understanding relationship between different people. This means that subjectivity must play their own subjectivity in the range of consensus with each other. Accordingly, the emphasis on the relationship between teacher-student relationships is the interaction between subjects, namely intersubject relationship. While exchanges extended to all areas of student life, the educational process is a multi-polar subjectivity carried around a common object interaction process.

On the one hand, communication theory gives the student subject position, emphasizing to treat students as emotional, personality, self-seeking "people", not just equivalently as passive, negative "objects" that recognized as manage and control objects of teachers and school administrators. On the other hand, communication theory emphasizes the relationship between students and teachers, between managers is to "Participation - Cooperation" relationship established on the basis of a common intermediary object, making educational activities to become three main school participation, sharing knowledge, wisdom and outcomes. Students of subjectivity promoted in the process of "Participation - Cooperation".

In fact, both Dewey's democratic education and post-modernism require students to highlight its dominant position in the process of participation, to enhance the consciousness and personality, so as to develop students' subjectivity effectively.

\section{CONCLUSION}

In summary, many points of view are provided a strong philosophical basis for student participation. Student participation is not only the inevitably require of people-oriented school management and the main goal of subjective education, but also the effective ways to protect the students' right to speak and develop student subjectivity. Therefore, Student participation should be given appropriate attention from the education sector to improve the quality of teaching, so as to build a harmonious campus.

\section{REFERENCES}

[1] [America] Thomson wrote. Geng Danru translated. Economic and Social History of the Middle Ages. Commercial Press. 1984.

[2] John Brubaker wrote. Wang Chengxu, Xu Xiaozhou translated. Philosophy of Higher Education. Zhejiang Education Publishing House. 2001(9).

[3] Zheng Leping. Beyond Modernism and Postmodernism On the Construction of New Social Theory Space Shanghai: Shanghai Education Press, 2003.

[4] Xu Hui, Xie Yiquan. Discourse Hegemony and Equal Exchange - Thoughts on the New Concept of Teachers and Students Education Science .2004(2).

[5] Xu Jianling. Participatory Teaching in UniversityTheoretical Discussion and System Construction. China Ocean University Press. 2006.

[6] [Germany]Habermas. Preparatory Studies and Supplementary Material on the Theory of Communicative Action. Ai Silin. Habermas on "Living World", Qiushi Journal. 1995(5). 